\title{
コンクリート充填円形鋼管を用いた ラーメン隅角部の静的耐荷力特性
}

\author{
堀地 紀行 $^{1}$ - 保坂 鐵矢 $^{2}$ - 依田 照彦 $^{3}$ - 勝尾 伸一 ${ }^{4}$ \\ '正会員 工博 国士舘大学教授 工学部土木工学科（テ154-8515 東京都世田谷区世田谷 4-28-1） \\ （元日本鉄道建設公団 設計技術室） \\ 2 正会員 工博 元日本鉄道建設公団 設計技術室（干100-0014 東京都千代田区永田町 2-14-2） \\ 3 フェロー会員 工博 早稲田大学教授 理工学部土木工学科（T169-8555 東京都新宿区大久保 3-4-1） \\ 4 正会員 日本シビックコンサルタント株式会社＼cjkstart技術研究部（テ116-0013 東京都荒川区西日暮里 2-26-2）
}

\begin{abstract}
本論文は, コンクリートを充填した円形鋼管で構成されたラーメン隅角部の静的耐荷力特性を載荷実験, およびF E M解析にて確認し，それによって得られた知見を述べたものである. 載荷実験では, コンクリー 卜を充填しない供試体 1 体と充填した供試体 3 体を製作し実験を実施した。 また, F E M 解析では, 載荷実 験のモデルを含め計 6 モデルについて解析した. 円形鋼管にコンクリートを充填した際の耐荷力の増分は, 補剛材の有無, 位置に大きく依存せず, おおむね一定の值を示した. また，はり・柱部にコンクリート充填 円形鋼管を用いたモデルは，コンクリート未充填型モデルや，はり部に充填角形鋼管を適用したモデルと比 較し、ほぼ 2 倍程度のじん性率を示した.
\end{abstract}

Key Words : concrete filled circular steel pipe, composite member corner joint, ductility, ultimate strength

\section{1.はじめに}

鋼・コンクリートの合成柱や合成ばりは，引張に対して じん性に富んだ鋼材と圧縮に対して有利なコンクリートを 一体化した構造物で，耐荷力と剛性に富み，耐震性にも優 れていると言われている. また，施工面においても型枠・ 鉄筋工が不要であったり, 補剛材が省略できる等の利点を 有する構造形式であり，構造を選定する上で鉄筋コンクリ 一ト構造, プレストレストコンクリート構造, 鋼構造と比 較しても施工性・経済性・耐久性に関して，優れている面 が多く認められる.このため近年では，道路や鉄道の橋梁 にも適用される例がしばしば見受けられるようになってき た.
こうした背景を踏まえ, コンクリートを充填した円形鋼 管柱 ${ }^{1,2)}$ および円形鋼管ばり ${ }^{3)}$ の力学特性についても, 数多 くの実験デー夕が整備され，その設計法（耐荷力評価法） も提案されている. また, ラ一メン構造においては長方形 断面にコンクリートを充填した隅角部の耐荷力に関する研 究も既に実施されており, 隅角部に発生するフランジのせ

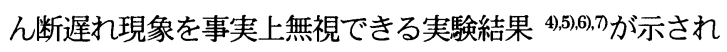
ている.

しかしながら, 円形鋼管を接続した隅角部の設計手法と

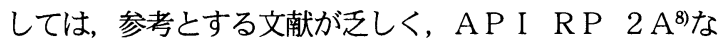
どに示される計算式を広義に解釈し, 引用せざるを得ない 状況にあり，コンクリートを充填したこのようなラーメン 隅角部の耐荷力評価法は，現段階では十分に整備されてい 
表一 1 供試体モデルと FEM 解析モデル

\begin{tabular}{|c|c|c|c|c|c|c|c|c|}
\hline $\begin{array}{c}\text { 供試体 } \\
\text { 番号 }\end{array}$ & $\begin{array}{l}\text { FEM } \\
\text { 解析 } \\
\text { 番号 }\end{array}$ & 柱寸法 & はり寸法 & $\begin{array}{l}\text { 充 } \\
\text { 填 }\end{array}$ & $\begin{array}{c}\text { 補岡惏 } \\
\text { 位置 }\end{array}$ & $\mathrm{D} / \mathrm{T}$ & $\mathrm{d} / \mathrm{t}$ & $\mathrm{d} / \mathrm{D}$ \\
\hline- & (1) & \multirow{7}{*}{$\begin{array}{c}\phi 558.8 \\
\times \\
12.7 \\
(\mathrm{STK} 400)\end{array}$} & \multirow{6}{*}{$\begin{array}{c}\phi 457.2 \\
\times \\
9.5 \\
\text { (STK400) }\end{array}$} & \multirow{3}{*}{ 無 } & - & 44 & 48 & 0.82 \\
\hline PS-1 & (2) & & & & $45^{\circ}$ & 44 & 48 & 0.82 \\
\hline- & (3) & & & & はり縁部 & 44 & 48 & 0.82 \\
\hline- & (4) & & & \multirow{3}{*}{ 有 } & - & 44 & 48 & 0.82 \\
\hline PS-2 & (5) & & & & $45^{\circ}$ & 44 & 48 & 0.82 \\
\hline PS3 & (6) & & & & はり縁部 & 44 & 48 & 0.82 \\
\hline PS-4 & - & & $\begin{array}{c}\square 400 \times \\
400 \times 9 \\
(\text { STKR400) }\end{array}$ & 有 & はり縁部 & 44 & - & - \\
\hline
\end{tabular}

表一 1中のD,Tは柱部材の外径, 板厚, $\mathrm{d}, \mathrm{t}$ ははり部材の外径, 板㫗を示す，また，充填有りは，柱とはりの全てにコンクリート を充填したものである.

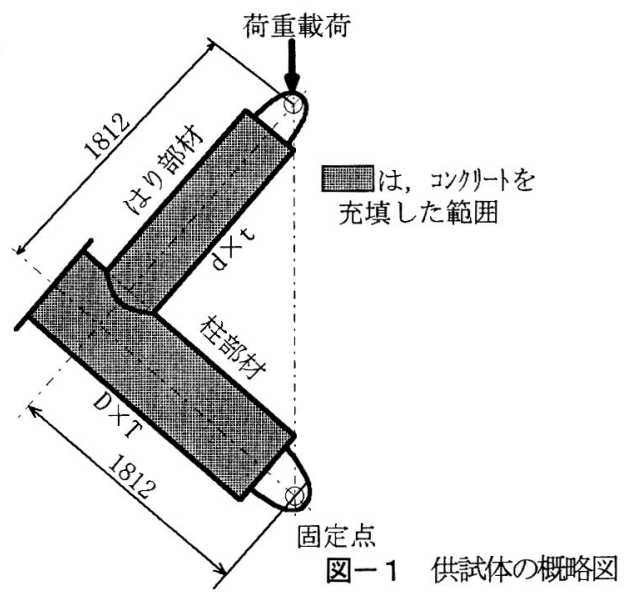

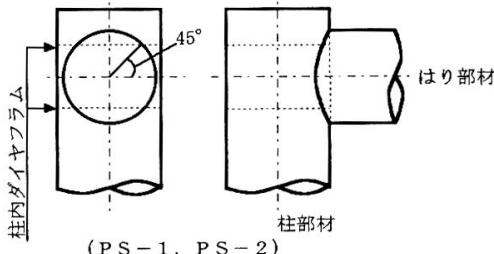

(a) 補㣚材 $45^{\circ}$ 配置

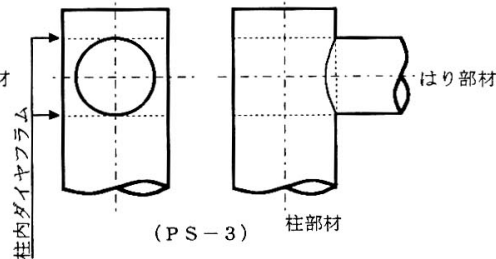

(b) 補剛材端部配置

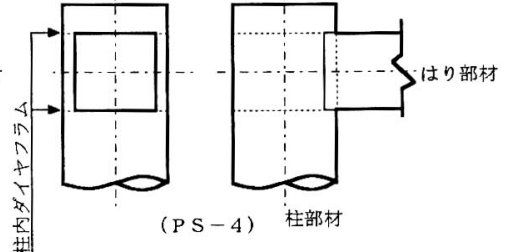

(c) 補岡材端部配置

図一 2 柱内ダイヤフラムの位置

\section{るとは言い難い!}

本論文では，コンクリートを充填した円形鋼管で構成さ れたラーメン隅角部について静的載荷実験，およびF EM 解析を行い，その結果から耐荷力の評価手法を提示すると ともに，(1)コンクリートの充填効果，(2)柱部材内の補剛材 の位置 (ダイヤフラム位置) による応力発生状況の相違, (3はり部材の形状（円形と角形）の違いによる而荷力の相 違, (4)降伏耐力の判定, (5)降伏後のじん性評価, (6)応力集 中（接合部近傍）の状況，77破壊状況など，主に充填円形 鋼管を柱とはりに適用したラーメン隅角部の構造特性につ いて報告する.

\section{2. 静的載荷実験}

載荷実験に用いる供試体は，鉄道橋ラーメン高架橋の試 設計より，柱サイズ $\phi 1400 \times 28$, はりサイズ $\phi 1100 \times$ 22 と想定した.ここで採用したはり，柱の外径比（d/D = 0.8）は，鉄道橋等において柱部に致命的損傷を発生させな いことを前提としたためで，実験の結果もこうした前提条 件におけるはり部の挙動に着目することになる.
供試体の縮尺は $1 / 2.5$ として製作し，その材料強度の目 標值としては，鋼管の材質 : STK490, 充填コンクリート の設計基淮強度 : $30 \mathrm{MPa}$ としている(図一1参照).

\section{（1）供試体モデル}

載荷実験と F EM解析に用いたモデルを表ー1に示す. 供試体 (4体) の径厚比 (D/T, $\mathrm{d} / \mathrm{t})$ ) およひ外径比 (d/D) は試設計の結果と同程度のものを選定した。 また，F E M解析では，実験に対応した3ケース (2)，(5)，(6)）に 実験を補足する目的で，さらに3ケース (1)，(3)，(4) を加えた，合計6ケースについて解析した。

$\mathrm{PS}-1$ 〜 のモデルは, (1)コンクリート充填効果, (2) ダイヤフラム（柱内補剛材）位置の相違，(3)り部材が角 形の場合，の比較に着目して選定した. すなわち，P S 1は未充填型モデル，PS - 2はPS - 1に充填したモデ ル，PS－3はP S - 2とダイヤフラム位置が異なるモデ ル，PS－4ははり部材が角形のモデルとした.

$\mathrm{PS}-4$ のはり部材は，P S - 2, 3 とコンクリートが 未充填の状態で曲け岡性がほぼ等しい部材（円形ばり：I $=33,500 \mathrm{~cm}^{4}$ ，角形ばり： $\left.\mathrm{I}=35,100 \mathrm{~cm}^{4}\right)$ を用いている. 補戍惏である柱内ダイヤフラムの位置は，図一2の(b),(c) 
表一2 鋼材の材料試験結果

\begin{tabular}{|c|c|c|c|c|c|}
\hline 品種 & 材質 & $\begin{array}{l}\text { 試験片 } \\
\text { 寸法 } \\
\mathrm{t}(\mathrm{mm})\end{array}$ & $\begin{array}{c}\text { 降伏 } \\
\text { 強度 } \\
\sigma \mathrm{y}(\mathrm{MPa})\end{array}$ & $\begin{array}{l}\text { 降伏 } \\
\text { ひずみ } \\
\varepsilon \mathrm{y}(\mu)\end{array}$ & $\begin{array}{l}\text { 引張 } \\
\text { 強さ } \\
\text { (MPa) }\end{array}$ \\
\hline $\begin{array}{l}5558.8 \\
\times 12.7\end{array}$ & STK400 & 12. 25 & 348 & 1690 & 486 \\
\hline $\begin{array}{c}\phi 457.2 \\
\times 9.5\end{array}$ & STK400 & 9.34 & 350 & 1700 & 478 \\
\hline $\begin{array}{c}\square 400 \\
\times 400 \times 9\end{array}$ & STKR400 & 8.5 & 316 & 1534 & 436 \\
\hline $\begin{array}{c}\text { 名他弘 } \\
t=12 \mathrm{~mm}\end{array}$ & SS400 & 12. 05 & 322 & 1564 & 458 \\
\hline
\end{tabular}

$\varepsilon \mathrm{y}=\sigma \mathrm{y} / \mathrm{E}: \mathrm{E}$ は鋼材のヤング保数

表一3 充填コンクリートの配合
\begin{tabular}{|c|c|}
\hline 設計基準強度 & $29.4 \mathrm{MPa}$ \\
\hline 水セメント比 & $46.00 \%$ \\
\hline 細骨材率 & $39.60 \%$ \\
\hline 水 & $1,598 \mathrm{~N} / \mathrm{cm}^{3}$ \\
\hline セメント & $3,472 \mathrm{~N} / \mathrm{cm}^{3}$ \\
\hline 細骨材 & $6,855 \mathrm{~N} / \mathrm{cm}^{3}$ \\
\hline 粗骨材 & $10,856 \mathrm{~N} / \mathrm{cm}^{3}$ \\
\hline 混和剤 & $8,385 \mathrm{~N} / \mathrm{cm}^{3}$ \\
\hline
\end{tabular}

表-4 各種試験結果

\begin{tabular}{|c|c|c|c|c|}
\hline \multirow{2}{*}{\multicolumn{3}{|c|}{ 試験結果 }} & \multicolumn{2}{|c|}{$\mathrm{PS}-2 \sim \mathrm{PS}-4$} \\
\hline & & & はり & 柱 \\
\hline 只 & 空気量 & $\%$ & 4.5 & 4.5 \\
\hline 啠 & スランプ & $\mathrm{cm}$ & 13.5 & 13.5 \\
\hline 管 & \begin{tabular}{|} 
練上がり \\
温度
\end{tabular} & ${ }^{\circ} \mathrm{C}$ & 24.0 & 24.0 \\
\hline 材 & 压縮強度 & $\mathrm{MPa}$ & 33.0 & 42.4 \\
\hline 料 & 静弾性係数 & $\times 10^{4} \mathrm{MPa}$ & 3.259 & 3.459 \\
\hline
\end{tabular}

注 : 材料試験は, 載荷試験日の值を示す。

に示すようにはり部材の上下縁部に配置したモデル（P S -3, P S -4）と図一 20(a)に示すはり部材断面中心か ら約 $45^{\circ}$ の位置に配置したモデル (P S-1, PS - 2) を採用した。

\section{a) 材料特性}

鋼管はSTK400およびSTKR400, ダイヤフラムはSS400 とし，実施を考慮し SM490 材相当の降伏強度 $\sigma \mathrm{y}=314$ $\mathrm{MPa}$ を確保できる材料を用いた. 鋼材の材料訌験結果を, 表一2 と図一3 (b) に示す。 また，充填コンクリートの呼 ひ強度は， $\sigma \mathrm{ck}=30 \mathrm{MPa}$ の普通コンクリートとした. そ の配合，および各種試験結果を表一3，表一 4 と図一3 (a) に示す. なお，表一4における柱部に充填されたコンクリ 一ト強度の打設帕ら生じた材令差によるこの程度の差異 については，本実験の結果に与える影響，とりわけ，はり 部の挙動に与える影響は微少と考えられ，差し支えないも のと判断した.

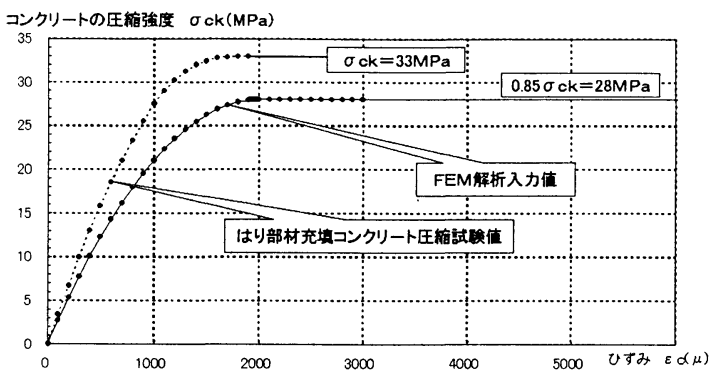

図ー3 (a) 充填コンクリートの応力ーひずみ特性

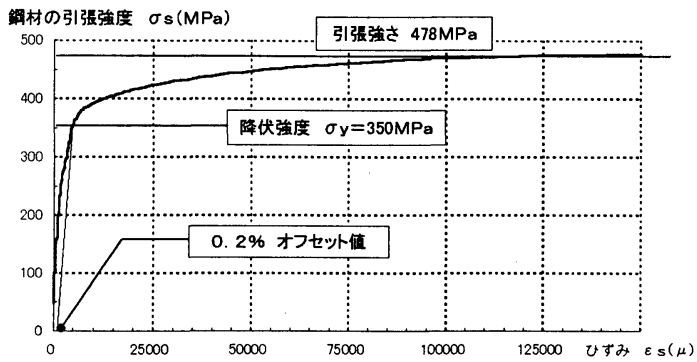

図ー3 (b) 鋼材の応力ーひずみ特性

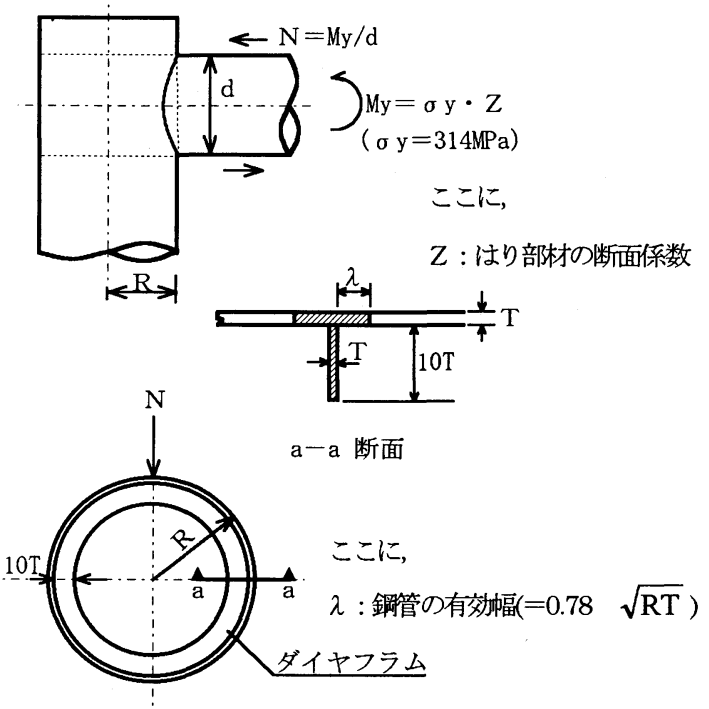

図-4 ダイヤフラムの剛度

\section{b ）ダイヤフラムの剛性}

現状では，ダイヤフラムの剛性を決める確立した基淮が ないため, 道路橋示方書 9の格点構造を参考に剛性を決定 した. ダイヤフラムの板厚は柱部材の板厚と同等とし, そ の自由突出幅は弾性域で局部座屈が生じない範囲である板 厚の 10 倍（10T）とした. また, ダイヤフラムで補剛さ れている部分（図一4）の必要剛度についても同示方書に 従って式(1)にて確認した. 

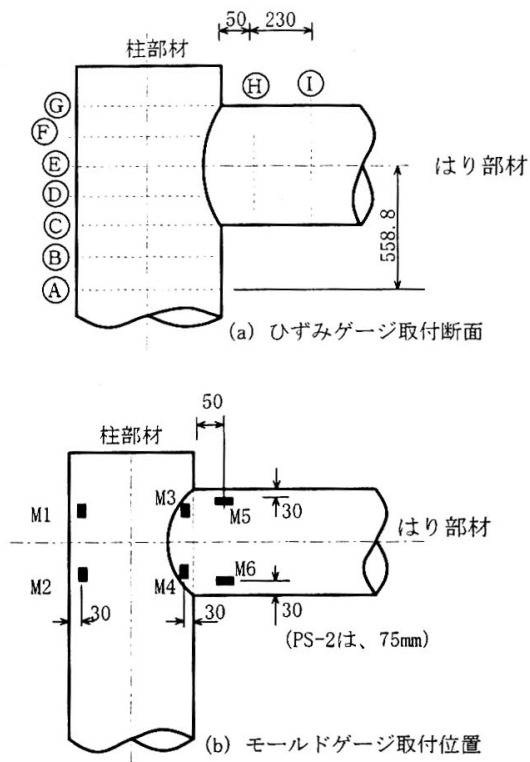

図-5 ゲージ取付断面（PS - 4 も同じ位置）

$$
\delta=0.045 \frac{\mathrm{N} \cdot \mathrm{R}^{3}}{\mathrm{EI}}<\frac{\mathrm{R}}{500}
$$

ここに, $\delta:$ 格点部変位量

$\mathrm{N}:$ 格点部に作用する軸力

$\mathrm{R}$ : 鋼管の半径

E I : 補剛部の剛度（図一 4 a-a 断面斜線部）

\section{c）供試体の製作}

供試体の製作にあたり，最も注意した点は，柱とはりの 溶接部である. 本接合部は，はりを柱の形状に合わせて曲 線に切断し, 接合は全断面溶込み溶接にて行った. また, 浸透探傷試験にて溶接部表面に欠陥が無いことを確認し， さらに，目視にて溶接ビード状況を，また，はり内部から は溶け込みの状况を確認した.

柱内ダイヤフラムの溶接は本来であれば全断面溶込み溶 接とすべきであるが，コンクリートの充填効果を期待した コストダウン，実験結果に対する安全サイドの評価，供試 体の大きさを考慮して片側全周すみ肉溶接を用いた. また, 柱頭部には柱の円周方向の変形を拘束するため, 柱の板厚 相当の蓋を片側全周すみ肉溶接にて固定した.

充填コンクリートの打設は柱とはりに分け，はりは端 部から，柱は頭部から打設した．打設にあたって，コン クリートがダイヤフラム周りにも密に充填されるように

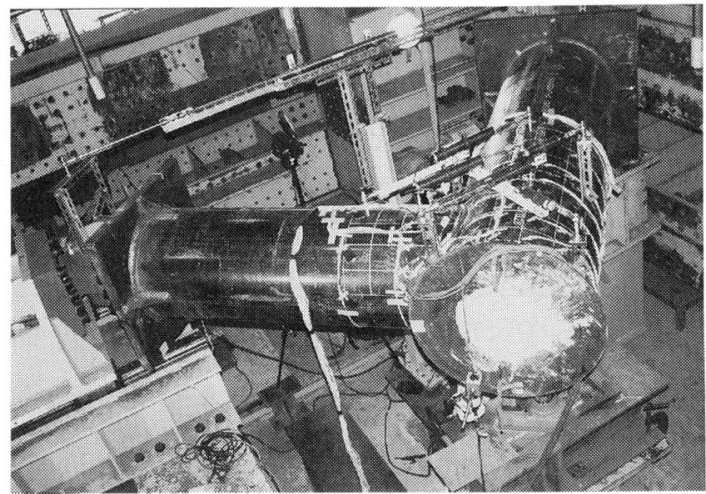

写真- 1 載荷実験の状況写真

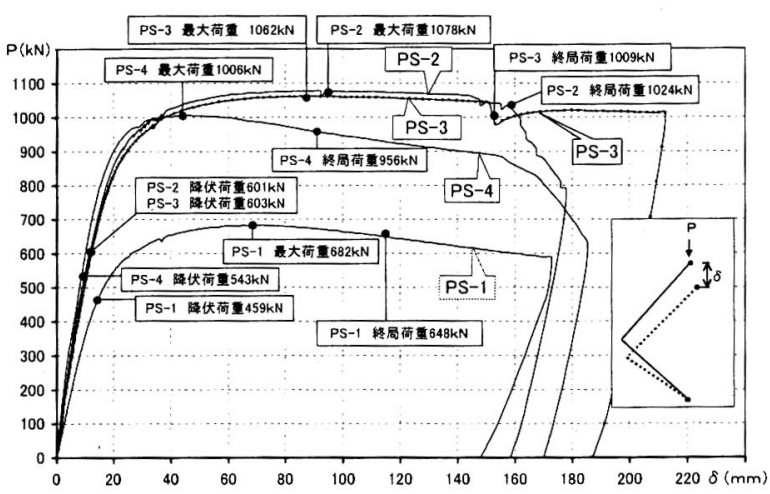

図-6 荷重一変位 $(P-\delta)$ 曲線

バイブレターを使用しながら比較的ゆっくり作業を進め た.

ひずみゲージおよびモールドゲージの取り付け位置を， 図一 5 に示す. なお，ひずみゲージは $22.5^{\circ}$ 間隔に配置し た.

\section{（2）載荷実験結果}

写真－1 に載荷実験の状況写真を示す．荷重の載荷方向 は, 部材に圧縮力が作用する方向に静的に単調載荷した. これは，実際に近い断面力を再現することは難しいので， 隅角部の基本的特性を調べるため自重などの常時荷重によ る荷重方向を想定して, 部材に圧縮力が作用する方向に載 荷した.

載荷実験では，隅角部のひずみをモニタリングしながら 荷重を静的に単調増加させ，破壊に至るまで載荷した．

$\mathrm{P} \mathrm{S}-1 \sim 4$ の荷重一変位 $(\mathrm{P}-\delta)$ 曲線図を図一 6 に示 し, 以下では載荷実験の状况を述べる. 


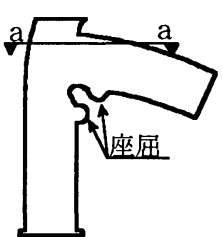

破壊には至らない 断面 $\mathrm{a}$ - $\mathrm{a}$

(a) $\mathrm{P} \mathrm{S}-1$

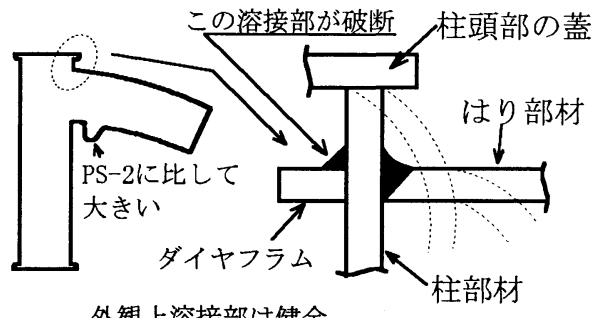

外観上溶接部は健全

(c) $\mathrm{P} \mathrm{S}-3$

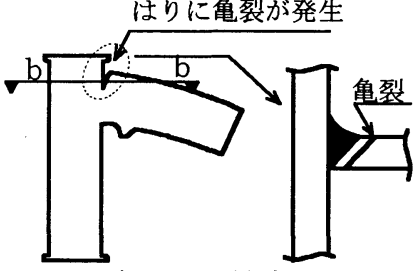

溶接部は健全

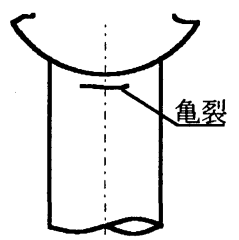

断面 $\mathrm{b}-\mathrm{b}$ (b) $\mathrm{P} \mathrm{S}-2$

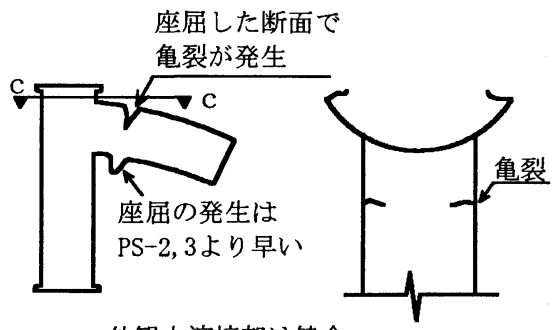

外観上溶接部は健全 断面 $\mathrm{c}-\mathrm{c}$

(d) $\mathrm{P} \mathrm{S}-4$

図一7 破壊（載荷実験終了時）の形状

\section{a ）載荷実験状況}

\section{- PS-1 (未充填型, 補剛材 $45^{\circ}$ 配置)}

$\mathrm{P}-\delta$ 曲線の傾きがほほ直線（弾性範囲）であるのは載 荷荷重 $500 \mathrm{kN}$ 付近までで，それを超えた時点から $\mathrm{P}-\delta$ 曲線が傾き始める. 載荷荷重 $600 \mathrm{kN} （ \delta=25 \mathrm{~mm}$ )を超え てから，はり接合部圧縮側（はり接合部より約 $100 \mathrm{~mm}$ の 位置，図一7(a)参照) に提灯座屈（局部座屈）が目視で確 認できた. 最大荷重時 $(682 \mathrm{kN}, \delta \mathrm{m}=72.0 \mathrm{~mm})$ には, はり接合部の圧縮側において柱がへこむような変形が確認 された. その後, 座屈によって生じた変形が進行するだけ であるため $\delta=170 \mathrm{~mm}$ にて実験を終了した. 実験終了後 の供試体は，はりの座屈部の断面で見ると，真円状態から 楕円へと大きく偏平していた，また， $\mathrm{P}-\delta$ 曲線に極端な 変化が認められないことから亀裂の発生はなかったものと 判断できる.

\section{- PS-2（充填型, 補岡材 $45^{\circ}$ 配置)}

$\mathrm{P}-\delta$ 曲線の傾きがほぼ直線であるのは載荷荷重 $800 \mathrm{kN}$ 付近までで，載荷荷重 $850 \mathrm{kN} （ \delta=20 \mathrm{~mm}$ ）を超えた付近 で $\mathrm{P}-\delta$ 曲線の傾きが変化し始めるものの，実験中，座屈 の発生は目視では確認できなかった. その後, 最大荷重 $(1,078 \mathrm{kN}, \quad \delta \mathrm{m}=94.7 \mathrm{~mm})$ に達してもP S-1のよう
な耐荷力の低下は見られず，目視でのはり接合部の座屈も 確認できなかった，さらに変位を増加させても耐荷力の低 下は認められず， $\delta=150 \mathrm{~mm}$ 付近から耐荷力が減少し始 め， $\delta=160 \mathrm{~mm}$ を越えて，急激に耐荷力が低下した．実 験終了後の供試体の観察において，はり部はP S - 1 と同 じ位置にわずかな座屈の発生（はり接合部より約 $100 \mathrm{~mm}$ の位置，図ー7(b)参照) が認められたが，その度合いはP $\mathrm{S}-1$ に比較して極めて小さく，座屈発生時点の荷重は本 載荷実験からは限定できなかった．また，柱部材の座屈は 目視では確認できなかった.

\section{- PS-3 (充填型, 補岡材端部配置)}

$\mathrm{PS}-3$ の $\mathrm{P}-\delta$ 関係はP $\mathrm{S}-2$ と比較し, 最大荷重 $(1,062 \mathrm{kN}, \delta \mathrm{m}=87.1 \mathrm{~mm})$ 楉干小さいものの, 弾性 域から塑性域にかけての傾向はほほ同じ結果となった. $\mathrm{P}$ $\mathrm{S}-2$ で亀裂が発生した $\delta=150 \mathrm{~mm}$ 付近では, はりの圧 縮側の提灯座屈は目視で確認されていた.この近傍で $80 \mathrm{kN}$ 程度の急激な荷重低下が認められたものの，はり接合部に は亀裂の発生は確認できなかったため，実験を続行した。 その後は変位が増加してもはり圧縮側の提灯座屈（はり接 合部より約 $100 \mathrm{~mm}$ の位置，図一7(c)参照) が進行するだ けなので， $\delta=210 \mathrm{~mm}$ までで載荷実験を終了した．座屈 


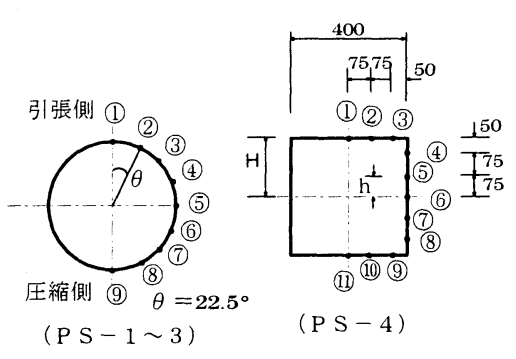

はり部材 (用 断面のひずみ測定点

図一8 着目した鋼材ひずみ位置

発生時点はP S -2 と同様に限定できない. $\delta=150 \mathrm{~mm}$ 付近の荷重低下原因は, 実験後の供試体の解体により確認 を行ったが, 柱内補剛材溶接部の破断と想定することが妥 当と考えられる.

柱部材のはり圧縮側接合部の近傍がP S - 1のようにへ こむような変形は確認できなかった. しかし，はり部材に おける引張側接合部付近には, 顕著なたわみ角が認められ た.

\section{-PS - 4（充填型, 補剛材端部配置, 角形ばり）}

弾性範囲（載荷荷重 $800 \mathrm{kN}$ 付近まで）における $\mathrm{P}-\delta$ 関係は, P S - 2 およびP S - 3 とほぼ同じであるが, 最 大荷重（1,006kN， $\delta \mathrm{m}=44.7 \mathrm{~mm} ）$ を超えてから荷重が 徐々に低下し始めた. はり部材圧縮側フランジに局部座屈 が発生したのもこの時点からで, 目視でも確認できた. $\delta$ $=150 \mathrm{~mm}$ 付近で座屈が発生している断面の引張側（フラ ンジと腹板の交点）には亀裂が認められたが，柱部材の座 屈については目視では確認できなかった.

はり部材接合部(図一 5 (a)に示す円断面) のひずみ分布 を図ー10 (d) に示す.これによると載荷荷重 $700 \mathrm{kN}$ 付近ま では, 引張フランジに取付けたひずみゲージ 3 点のひずみ (図中の(1),(2),(3) がほぼ等しいことからせん断遅れ現象 が生じていないことがわかる.

\section{b）破壞（載荷実験終了時）形状}

実駼終了時の破壊形状を図一 7 に示した. P S - 1〜 4 の破壊形状から以下のことが判明した. (1)充填型の場合, 未充填型で発生した柱がへこむよう変形は発生しなかっ た. (2はりが角形の場合, 座屈が進行している断面の引張 側で破断が生じた. (3)りが円形の場合, はり引張側の溶 接部付近（はり溶接部またはダイヤフラム溶接部）で破断 が生じた. (4)充填型の破断時の変位はいずれも $150 \mathrm{~mm}$ 付
表-5 降伏時荷重，および最大荷重

\begin{tabular}{|c|c|c|c|c|c|c|}
\hline & $S-1$ & $\mathrm{PS}-2$ & $\mathrm{PS}-3$ & $S-4$ \\
\hline \multicolumn{3}{|c|}{ 柱最初に降伏する位置 } & 圧縮側 & (C)引張側 & (D)引張側 & 圧縮側 \\
\hline \multirow[t]{2}{*}{ 部 } & 載荷荷 & & $13 \mathrm{kN}$ & $1.073 \mathrm{kN}$ & $1,004 \mathrm{kN}$ & $990 \mathrm{kN}$ \\
\hline & 変位 & & $2 \mathrm{~mm}$ & $71.2 \mathrm{~mm}$ & $36.4 \mathrm{~mm}$ & $31.2 \mathrm{~mm}$ \\
\hline \multicolumn{3}{|c|}{ 柱部材降伏ひずみ } & \multicolumn{4}{|c|}{$1690 \mu$} \\
\hline \multicolumn{3}{|c|}{ はり部材降伏ひずみ } & \multicolumn{3}{|c|}{$1700 \mu$} & $1534 \mu$ \\
\hline \multirow[b]{3}{*}{ は } & \multirow{3}{*}{ 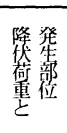 } & 降伏部位 & (iit) $-(7)$ & (H) $-(3)$ & (i) -(9) & (i) -(2) \\
\hline & & 降伏荷 & $459 \mathrm{kN}$ & $601 \mathrm{kN}$ & $603 \mathrm{kN}$ & $543 \mathrm{kN}$ \\
\hline & & 変 位 & $13.2 \mathrm{~mm}$ & $10.0 \mathrm{~mm}$ & $10.0 \mathrm{~mm}$ & $8.9 \mathrm{~mm}$ \\
\hline & \multirow{4}{*}{$\begin{array}{l}\text { 最 } \\
\text { 藮 } \\
\text { 動 } \\
\text { 特 }\end{array}$} & $\begin{array}{l}\text { ひずみ } \\
\text { 最大部位 }\end{array}$ & & & (9) & (1-1) -1 \\
\hline & & ひずみ & $16,860 \mu$ & $52,383 \mu$ & $53,105 \mu$ & $22,172 \mu$ \\
\hline & & 載荷荷自 & $682 \mathrm{kN}$ & $1,078 \mathrm{kN}$ & $1,062 \mathrm{kN}$ & $1,006 \mathrm{kN}$ \\
\hline & & 変 位 & $72.0 \mathrm{~mm}$ & $94.7 \mathrm{~mm}$ & $87.1 \mathrm{~mm}$ & $44.7 \mathrm{~mm}$ \\
\hline
\end{tabular}

近であった. (5)はり部材の座屈は，4供試体とも接合部よ り約 $100 \mathrm{~mm}$ 離れた位置で発生した.

\section{c）鋼材のひずみ分布}

図ー9には，はり部材 $\mathrm{A}$ 断面（P S - 1 ～4）のひずみ 分布を示す. また, 図一10には同断面 $(\mathrm{PS}-1 \sim 4)$ の 荷重一ひずみ関係を示す.

表一 5 は, はり部材の鋼材ひずみが降伏ひずみに達した 時の荷重を図ー9から, その時の変位を図一6から読みと り, さらに, 最大荷重時の変位を図一6から, その時のひ ずみをデータから抽出し整理したもので, 柱部材について も同じくデータから抽出した. 表一 5 中の柱部材について は(A)〜@断面（図一 5 (a)参照）のひずみ測定点において 最初に降伏した位置を, また, はり部材については用断面 における最初に降伏した位置 (図ー8参照) を示している.

P S - 1 (未充填型) については, まずはり部材の圧縮 側田断面一(7)に降伏ひずみが発生し, 次に柱部材の圧縮側 (B)断面) に発生する. 一方, PS $-2 \sim 4$ (充填型) に ついては, 柱部材が降伏ひずみに達するのは, いずれも載 荷荷重 $1,000 \mathrm{kN}$ 近傍を超えてからである.

$\mathrm{P}-\delta$ 曲線（図一6）において隅角部の近傍のはり弾性 限界は 700 900kN 付近と読みとれる. また，柱部材か降 伏する荷重は $1,000 \mathrm{kN}$ 付近である事から, 隅角部の降伏 は前提条件であるはり，柱の外径比に則して，はり部材接 合部から始まることが確認された。

\section{d）コンクリートのひずみ分布}

図ー12 に引張側充填コンクリートに埋め込まれたモール ドゲージ（M2，M5）のひずみの推移を示す．本図で曲線 が急に折れ曲がっている点がクラック発生点と推測できる. 

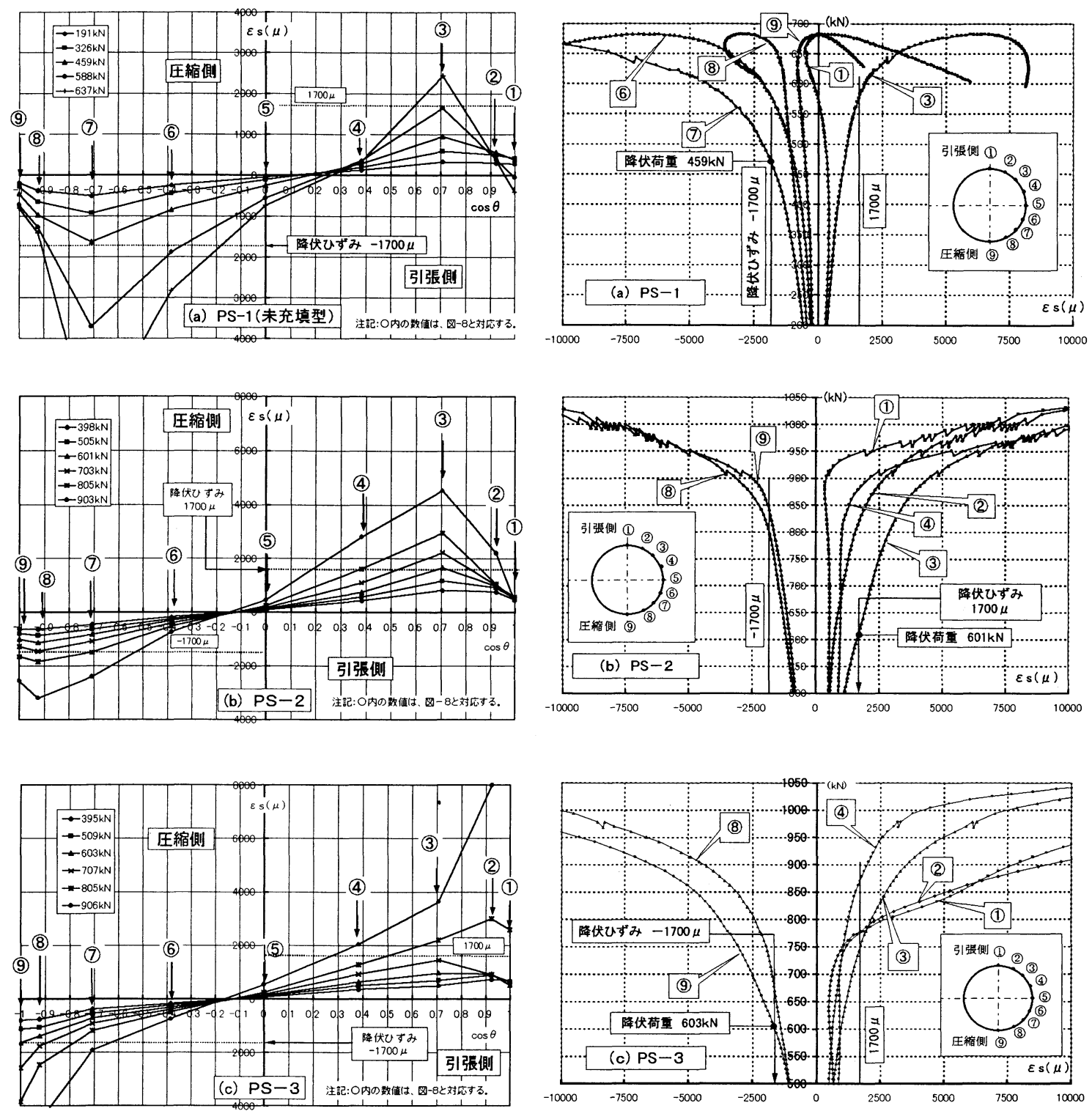

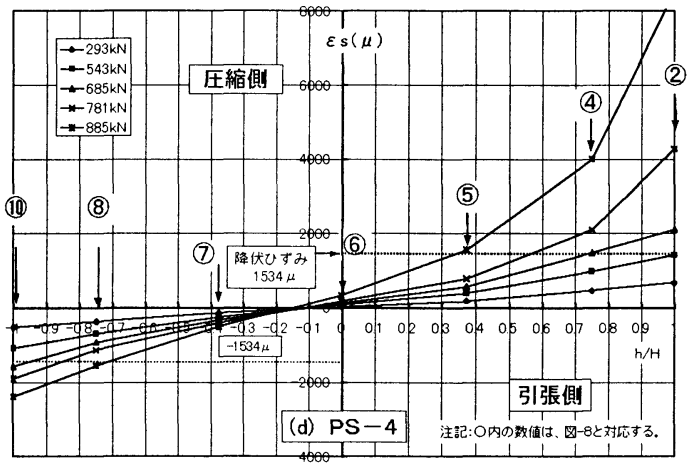

図ー9 はり部材(

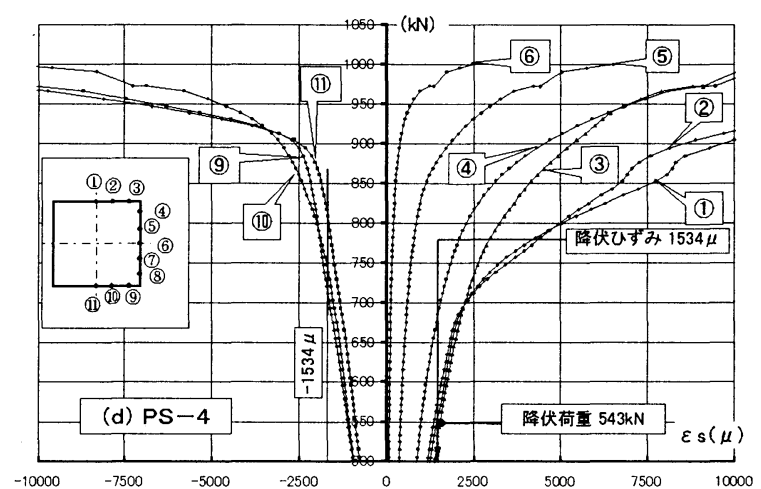

図ー10 ()断面の荷重一ひずみ関係 
表一6 引張コンクリートのモールドゲージかか

推定されるクラック発生

\begin{tabular}{|c|c|c|c|}
\hline \multicolumn{2}{|c|}{} & $\begin{array}{c}\text { クラック } \\
\text { 発生荷重 } \\
\text { の推定值 } \\
(\mathrm{kN})\end{array}$ & $\begin{array}{c}\text { クラック発生 } \\
\text { ひずみの } \\
\text { 推定值 } \\
(\mu)\end{array}$ \\
\hline \multirow{2}{*}{$\begin{array}{c}\text { 柱 } \\
\text { 部 }\end{array}$} & $\mathrm{PS}-2$ & 510 & 90 \\
\cline { 2 - 4 } $\mathrm{M} 2$ & $\mathrm{PS}-3$ & 690 & 70 \\
\cline { 2 - 4 } & $\mathrm{PS}-4$ & 220 & 70 \\
\hline \multirow{2}{*}{$\begin{array}{c}\text { 吉 } \\
\text { 部 } \\
\text { M5 }\end{array}$} & $\mathrm{PS}-2$ & 160 & 35 \\
\cline { 2 - 4 } & $\mathrm{PS}-3$ & 180 & 20 \\
\cline { 2 - 4 } & $\mathrm{PS}-4$ & 210 & 100 \\
\hline
\end{tabular}

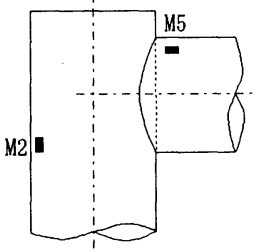

図ー11 モールドゲージ

設置図 (図一5力菗出)

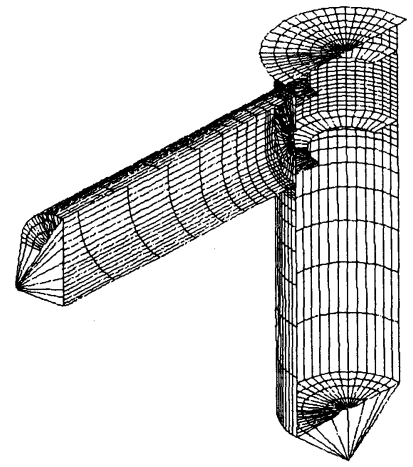

(a) シェル要素 (鋼材)
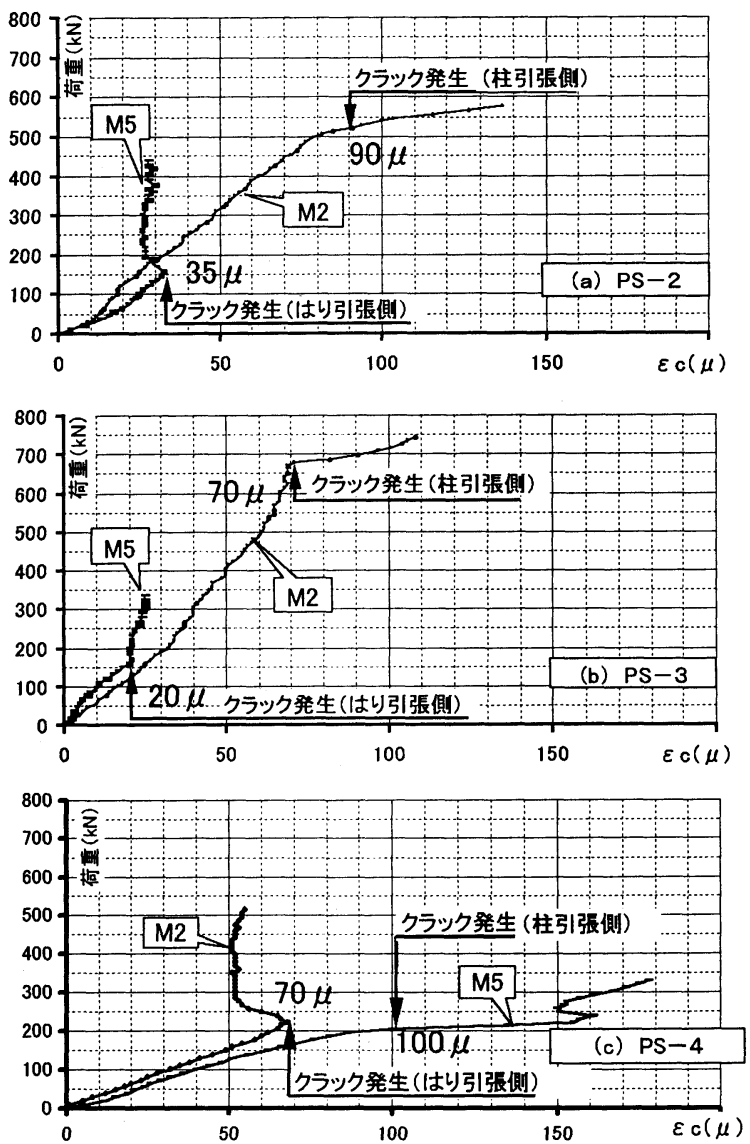

図-12 引張側充填コンクリートの荷重一ひずみ関係

表一6にクラック発生時の荷重とコンクリートのひずみ を示す.

はり部材に充填したコンクリートのクラックの発生時点 は3供試体とも大きな差はないが，ひずみではP S - 4が 他に比して大きな值を示している. これは，角形鋼管では 引張側フランジ面の鋼材とコンクリートの接触面積が広く, 両者の境界面が剥離することなく同じひずみで推移した結

\section{（b）ソリッド要素（コンクリート） \\ . 図-13 F EM解析モデル概要図}

果と推測できる．また，柱部材のクラック発生ひずみがは り部材に比較して大きい理由は，柱内ダイヤフラムの拘束 効果によるものと推測できる. さらに，比較的早い段階で 発生するはり部材の充填コンクリートのクラックは, 弾性 域で発生しているが，図－6の荷重一変位曲線が示す通り この領域において，荷重低下が起こらなかったことから， 隅角部の耐力低下要因とはならないことが判断できる.

\section{F EM解析結果}

F EM解析は，載荷実験と解析の整合，載荷実験の補足 などを目的として実施した.

\section{（1） FEM解析モデル}

F EM解析（使用ソフト : MARK 7.2）に用いる材料特 性，部材サイズなどは載荷実験前に行った材料試験結果(表 -2，3，図一3 (a)，(b))を参考に非線形材料特性を入 


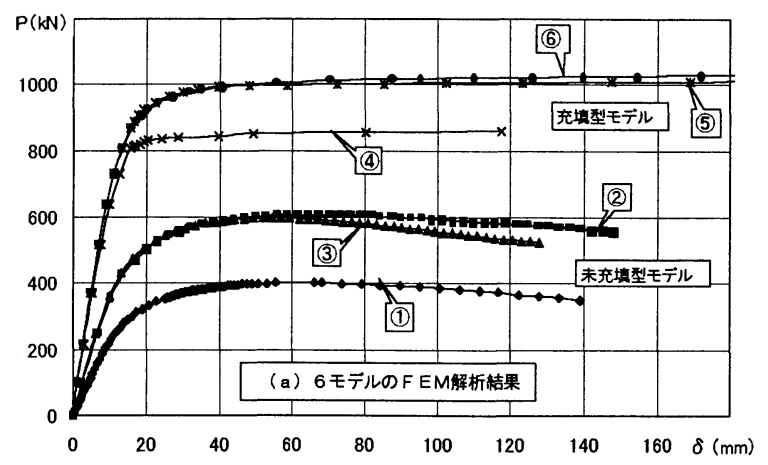

\begin{tabular}{|c|c|c|c|c|c|c|}
\hline \multirow{2}{*}{$\begin{array}{c}\text { FEM } \\
\text { モデル } \\
\text { 番号 }\end{array}$} & \multirow{2}{*}{$\begin{array}{c}\text { 供試体 } \\
\text { 番号 }\end{array}$} & \multirow{2}{*}{$\begin{array}{c}\text { 補岡忉 } \\
\text { 位置 }\end{array}$} & \multirow{2}{*}{ 充填 } & \multicolumn{2}{|c|}{ 最大荷重 $\operatorname{Pm}(\mathrm{kN})$} & \multirow{2}{*}{$\begin{array}{l}\text { 実験値 } \\
\text { 解析值 }\end{array}$} \\
\hline & & & & 解析值 & 実験值 & \\
\hline (1) & - & 無 & 無 & 401 & - & - \\
\hline (2) & PS-1 & $45^{\circ}$ & 無 & 605 & 682 & 1.13 \\
\hline (3) & - & 端部 & 無 & 595 & - & - \\
\hline (4) & - & 無 & 有 & 855 & - & - \\
\hline (5) & PS-2 & $45^{\circ}$ & 有 & 1,003 & 1,078 & 1.07 \\
\hline (6) & PS -3 & 端部 & 有 & 1,017 & 1,062 & 1.04 \\
\hline
\end{tabular}
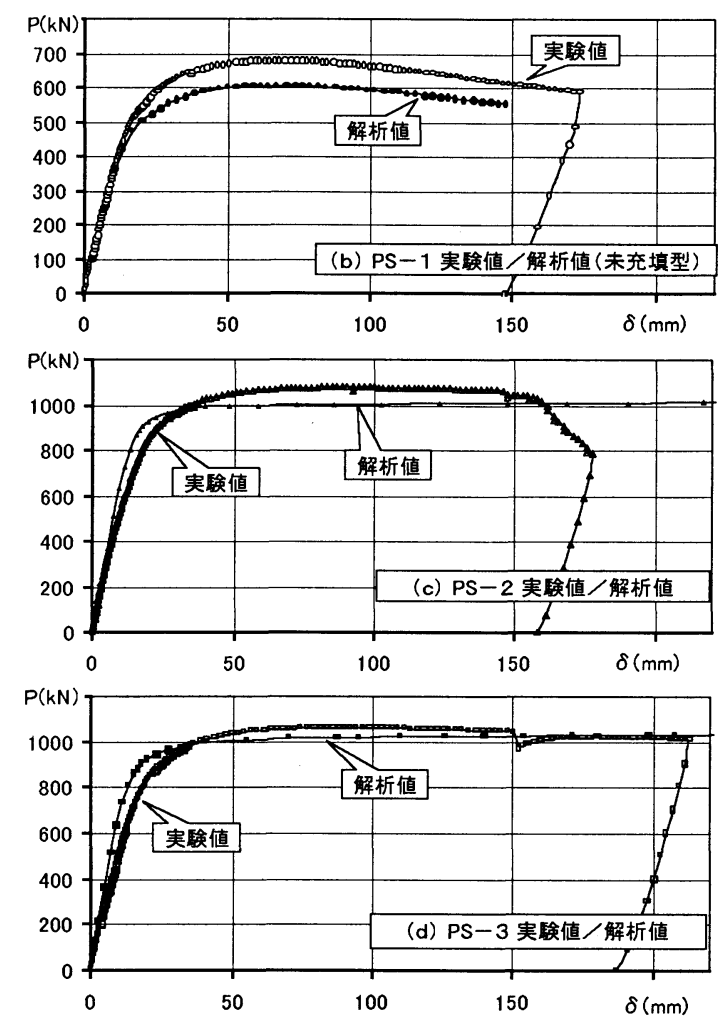

図-14 F EM解析結果 $\mathrm{P}-\delta$ 曲線

カした. ただし，コンクリートについては，文献 10)の 460 頁に示す応力ーひずみ曲線を用いた. また，鋼管は板要素， 充填コンクリートはソリッド要素を用いてモデル化し，溶 接部のビード形状やコンクリートの付着特性は考虑してい ない，なお，解析では塑性域での変形を忠実に表現するた め荷重増分ステップを出来る限り細かく入力し，実験結果 との整合を図った。

\section{（2）解析結果}

F EM解析では，柱内補剛無しモデルも含めて，(1)補剛 効果, (2)充填効果, (3)実験結果との整合, (4)ひずみ分布,

\begin{tabular}{|c|c|c|c|c|c|}
\hline \multirow{2}{*}{$\begin{array}{l}\text { 補㓮状才 } \\
\text { 位置 }\end{array}$} & \multicolumn{2}{|c|}{ 最大荷重 Pm(kN) } & \multirow{2}{*}{$\begin{array}{l}\text { 耐力 } \\
\text { 増分 } \\
\text { P1-P2 }\end{array}$} & \multirow{2}{*}{$\begin{array}{c}\begin{array}{c}\text { 増分率(\%) } \\
(\mathrm{P} 1-\mathrm{P} 2) \\
/ \mathrm{P} 2\end{array} \\
\end{array}$} & \multirow[b]{2}{*}{ 備考 } \\
\hline & $\begin{array}{c}\text { 充填型 } \\
\text { P1 }\end{array}$ & $\begin{array}{c}\text { 未充填型 } \\
\text { P2 }\end{array}$ & & & \\
\hline 無 & 855 & 401 & 454 & 113 & 解析値 \\
\hline \multirow{2}{*}{$45^{\circ}$} & 1,003 & 605 & 398 & 66 & 解析值 \\
\hline & 1,078 & 683 & 395 & 58 & 実験値 \\
\hline \multirow{2}{*}{ 端部 } & 1,017 & 595 & 422 & 71 & 解析值 \\
\hline & 1,062 & - & - & - & 実験値 \\
\hline
\end{tabular}

などを確認した. 図ー14(a)には，全モデル（表一1に示し た 6 モデル) の $\mathrm{P}-\delta$ 曲線を示す. 図一14(b) (d)には実 験值との比較を示す。

実験值と F EM解析值の比較では，(1)充填型では解析値 の方が弾性域で若干大きめの剛性を示した. (2)降伏荷重は 同程度であった．(3)最大荷重は実験值が大きい結果となっ た.

このことから判断して F EM解析は，ほぼ訃頼性のある 結果と言える. 表一7には, 解析値と実験值の最大荷重の 比を示す。 なお, 表中の太枠内は, 載荷実験と F EM解析 を行ったケースを示している。

\section{a ) コンクリート充填効果}

コンクリートを充填することによる効果を最大荷重に着 目して, その耐力増加分を表一8に示す. なお, 表中の太 字は載荷実験結果により得られた值を示す。

載荷実験と F EM解析を実施した補剛忉を $45^{\circ}$ に配置 したモデル（PS-1，2）において，耐力の増加分を見 ると約 $400 \mathrm{kN}$ であった. 解析で補足したモデルの比較に おいても, 補剛無の場合で約 $450 \mathrm{kN}$, 補岡忉を端部に配置 した場合で約 $400 \mathrm{kN}$ であり，コンクリートを充填するこ とによる効果は今回採用した構造系においては，おおむね $400 \mathrm{kN}$ と考えられる. 
表ー9 ダイヤフラムによる補強効果

\begin{tabular}{|c|c|c:c|c|}
\hline 充填 & 補岡忉才位置 & \multicolumn{2}{|c|}{ 耐为増分 $(\mathrm{kN})$} & 増分率 \\
\hline \multirow{2}{*}{ 無 } & $45^{\circ}$ & $605-401=$ & 204 & $51 \%$ \\
\cline { 2 - 5 } & 端部 & $595-401=$ & 194 & $48 \%$ \\
\hline \multirow{2}{*}{ 有 } & $45^{\circ}$ & $1,003-855=$ & 148 & $17 \%$ \\
\cline { 2 - 5 } & 端部 & $1,016-855=$ & 161 & $19 \%$ \\
\hline
\end{tabular}

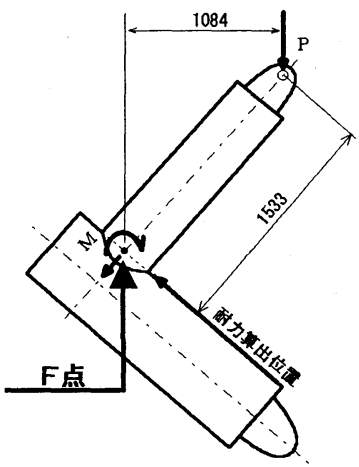

図-15 耐力比較位置

\section{b）ダイヤフラム補強効果}

供試体 4 体はすべてダイヤフラムをはり上下縁部もしく は，はり部材断面中心から $45^{\circ}$ 位置に配置しているため, ダイヤフラムにて補岡梳ることによる耐力増加分を解析值 を用いて比較した. 表一 9 に示す通りその増分は 150〜 $200 \mathrm{kN}$ であり，増分率で見ると充填型の方が効果が少ない と言える. これは，充填コンクリートが圧縮側の耐力の増 加に大きく寄与し，ダイヤフラムの補剛効果が直接的には 現れてこないものと推測される.

\section{4. 耐力評価（実験値と理論値の比較）}

実験值より供試体隅角部の耐力を降伏，および終局の状 態について推察し, 式 (4),(5) に示耐力評価式から求め られる理論値との比較を行った. 理論值を算定する際の着 目位置は，はり部材に局部座屈が発生する付近として，は り部材と柱部材の接合部の $\mathrm{F}$ 点（図一15参照）を基準と した. また, この時の曲げモーメント $\mathrm{M}(\mathrm{kN} \cdot \mathrm{m})$ と載荷 荷重 $\mathrm{P}(\mathrm{kN})$ は, $\mathrm{M}=(\mathrm{P} / \sqrt{2}) \times 1533 \mathrm{~mm}=1.084 \cdot \mathrm{P}$ $(\mathrm{kN} \cdot \mathrm{m})$ の関係となる.

\section{（1）降伏荷重の判定}

載荷実験結果による降伏荷重の判定は，部材の一部が
表一10 載荷荷重比較表 (単位 : $\mathrm{kN}$ )

\begin{tabular}{|c|c|c|c|c|}
\hline 供試体 & $\begin{array}{c}\text { 降伏荷重 } \\
\mathrm{Py}\end{array}$ & $\begin{array}{c}\text { 終局荷重 } \\
\mathrm{Pu}\end{array}$ & $\begin{array}{c}\text { 最大荷重 } \\
\mathrm{Pm}\end{array}$ & $\mathrm{Pu} / \mathrm{Py}$ \\
\hline $\mathrm{PS}-1$ & 459 & 648 & 682 & 1.41 \\
\hline $\mathrm{PS}-2$ & 601 & 1,024 & 1,078 & 1.70 \\
\hline $\mathrm{PS}-3$ & 603 & 1,009 & 1,062 & 1.67 \\
\hline $\mathrm{PS}-4$ & 543 & 956 & 1,006 & 1.76 \\
\hline
\end{tabular}

\begin{tabular}{|c|c|c|c|c|}
\multicolumn{7}{|c|}{ 表-11 各変位とじん性率の比較表 } & (単位 : mm) \\
\hline 供試体 & $\begin{array}{c}\text { 降伏変位 } \\
\delta \mathrm{y}\end{array}$ & $\begin{array}{c}\text { 終局変位 } \\
\delta \mathrm{u}\end{array}$ & $\begin{array}{c}\text { 最大荷重 } \\
\text { 時変位 } \\
\delta \mathrm{m}\end{array}$ & $\begin{array}{c}\text { じん性率 } \\
\mu=\delta \mathrm{u} / \delta \mathrm{y}\end{array}$ \\
\hline $\mathrm{PS}-1$ & 13.2 & 116.1 & 72.0 & 8.80 \\
\hline $\mathrm{PS}-2$ & 10.0 & 160.9 & 90.7 & 16.09 \\
\hline $\mathrm{PS}-3$ & 10.0 & 152.0 & 87.1 & 15.20 \\
\hline $\mathrm{PS}-4$ & 12.6 & 92.2 & 44.7 & 7.32 \\
\hline
\end{tabular}
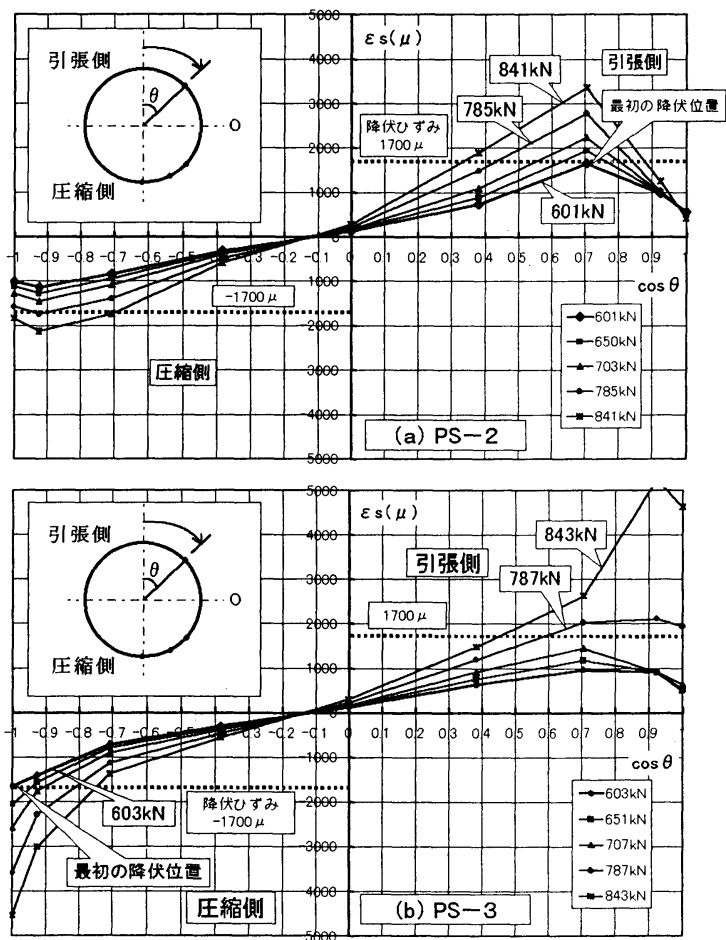

図-16 降伏荷重近傍の角断面ひずみ分布

降伏ひずみに到達する時点と定義し，表一 5 に示す降伏荷 重とした.

\section{（2）終局変位の判定}

終局変位は，図一6における最大荷重Pm の 95\%に相当 する荷重を終局荷重と定義し，それに対応する変位とした. 


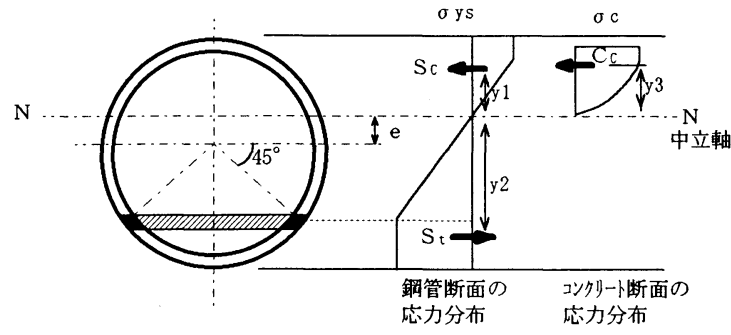

図一17 合成断面の降伏状態における応力分布
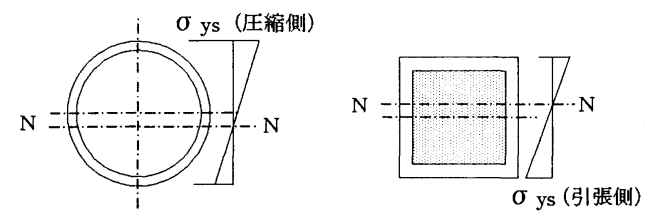

(a) $\mathrm{P} \mathrm{S}-1$ (未充填型)

(b) $\mathrm{P} \mathrm{S}-4$ (角形充填)

図一18 PS-1, 4 の降伏時応力分布

また，じん性率 》は終局変位 $(\delta \mathrm{u})$ と降伏変位 $(\delta \mathrm{y})$ を用いて，

$$
\mu=\delta \mathrm{u} / \delta \mathrm{y}
$$

とした.

表-10 に降伏荷重, 終局荷重, 最大荷重, 表-11 に各 荷重時の変位とじん性率を示す。ここで，充填円形鋼管を 用いた隅角部（PS - 2，3）の Pu，Pmはほほ同程度と なっている. また, じん性率 $\mu$ は, 15〜16 の值を示して おり,ラーメン構造のはり部材に充填円形鋼管を用いた場 合, 未充填円形金岡管, 充填角形鋼管と比較し, じん性率と して約 2 倍程度期待できることが確認された.

\section{（3）降伏，および最大荷重の実験値と理論值の比較}

コンクリート充填型円形銅管の終局曲げモーメントMcu は全断面が降伏した時を，降伏曲げモーメントMcy は引張 側鋼管が図ー17 に示すように $45^{\circ}$ の範用て降伏した時 ${ }^{10)}$ を理論上の降伏荷重と考えた. 図一16 には載荷実験におけ るPSー2,3のはり部材の接合部付近（接合部より $50 \mathrm{~mm}$ の位置) の降伏近傍のひずみ分布を示す．補岡忉の位置の 相違により, PSー2では, $45^{\circ}$ 付近で降伏に達し, また, $\mathrm{PS}-3$ では, 端部 $0^{\circ}$ 付近が降伏する. このため, 理論 計算式の応力分布の仮定と実験結果から得られた降伏荷重, 終局荷重の定義による応力分布とは異なるが，一つの目安 として比較を行っている.

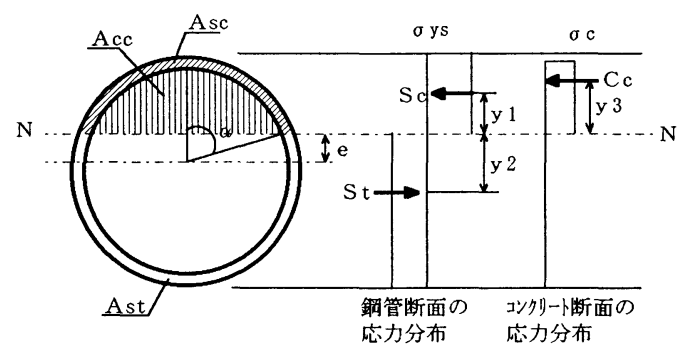

図-19 合成断面の全塑性状態における仮定応力分布

\section{a）降状曲げモーメント}

理論上の降伏曲げモーメントMcy は, 図ー17 に示す応 力分布の仮定をもとに式(3)にて中立軸を算定し, 式(4)にて 求めることができる.

$$
\begin{aligned}
& \mathrm{Sc}+\mathrm{Cc}-\mathrm{St}=0 \\
& \mathrm{Mcy}=\mathrm{Sc} \cdot \mathrm{y}_{1}+\mathrm{St} \cdot \mathrm{y}_{2}+\mathrm{Cc} \cdot \mathrm{y}_{3} \\
& \beth こ k, \\
& \mathrm{~S}_{\mathrm{C}}: \text { 鋼材の圧縮側合力 } \\
& \mathrm{C}_{\mathrm{C}}: \text { コンクリートの圧縮側合力 } \\
& \mathrm{S}_{\mathrm{t}}: \text { 鋼材の引張側合力 } \\
& \mathrm{y}_{1}: \mathrm{Sc} \text { から中立軸までの距離 } \\
& \mathrm{y}_{2}: \mathrm{St} \text { から中立軸までの距離 } \\
& \mathrm{y}_{3}: \mathrm{Cc} \text { から中立軸までの距離 }
\end{aligned}
$$

また, PS - 1，4の降伏時応力分布は図一18 とした.

\section{b）全塑性曲げモーメント}

全塑性曲げモーメントMcu は, 図ー19 に示す応力分布 を仮定し，式(5)にて求めることができる.

$\mathrm{Mcu}=\sigma \mathrm{ys} \cdot \mathrm{Asc} \cdot \mathrm{y}_{1}+\sigma \mathrm{ys} \cdot \mathrm{Ast} \cdot \mathrm{y}_{2}+\mathrm{fc} \cdot \mathrm{Acc} \cdot \mathrm{y}_{3}$

ここに,

断面積 : A

充填部 : $\mathrm{Acc}=\mathrm{Di}^{2} \cdot(\alpha-\sin \alpha \cdot \cos \alpha)$

鋼管圧縮部 : $\mathrm{Asc}=\mathrm{Dm} \cdot \mathrm{t} \cdot \alpha$

鋼管引張部 : $\mathrm{Ast}=\mathrm{Dm} \cdot \mathrm{t} \cdot(\pi-\alpha)$

$$
\alpha=\cos ^{-1}(2 \mathrm{e} / \mathrm{Dm})
$$

断面係数: $\mathrm{G}$

充填部 : $\mathrm{Gcc}=\mathrm{Di}^{3} \cdot \sin ^{3} \alpha$

鋼管圧縮部 : $\mathrm{Gsc}=\mathrm{Dm}^{2} \cdot \mathrm{t} \cdot \sin \alpha / 2$

鋼管引張部 : $\mathrm{Gst}=\mathrm{Dm}^{2} \cdot \mathrm{t} \cdot \sin \alpha / 2$

$\mathrm{Di}$ ：鋼管内径

$\mathrm{Dm}:$ 鋼管中心径 
表 -12 理論值と実験值の比較

\begin{tabular}{|c|c|c|c|c|c|c|c|c|}
\hline & \multicolumn{4}{|c|}{ 理論値 } & \multicolumn{2}{|c|}{ 実験值 } & \multicolumn{2}{|c|}{ 実験值／理論值 } \\
\hline & \multicolumn{2}{|c|}{ 降伏荷重 } & \multicolumn{2}{|c|}{ 全断面降伏荷重 } & \multirow{2}{*}{\begin{tabular}{|c|} 
降伏荷重 \\
$\begin{array}{c}\mathrm{Py} \\
(\mathrm{kN})\end{array}$ \\
\end{tabular}} & \multirow{2}{*}{$\begin{array}{c}\text { 最大荷重 } \\
\mathrm{Pm} \\
(\mathrm{kN}) \\
\end{array}$} & \multirow[b]{2}{*}{$\mathrm{Py} / \mathrm{Pcy}$} & \multirow[b]{2}{*}{$\mathrm{Pm} / \mathrm{Pcu}$} \\
\hline & $\begin{array}{l}\text { Pcy } \\
(\mathrm{kN})\end{array}$ & $\begin{array}{c}\begin{array}{c}M c y \\
(\mathrm{kN} \cdot \mathrm{m})\end{array} \\
\end{array}$ & $\begin{array}{l}\text { Pcu } \\
(\mathrm{kN}) \\
\end{array}$ & $\begin{array}{c}\mathrm{Mcy} \\
(\mathrm{kN} \cdot \mathrm{m})\end{array}$ & & & & \\
\hline PS-1 & 423 & 458 & 582 & 630 & 459 & 682 & 1.09 & 1.17 \\
\hline PS-2 & 660 & 715 & 773 & 837 & 601 & 1,078 & 0.91 & 1.39 \\
\hline PS-3 & 660 & 715 & 773 & 837 & 603 & 1,068 & 0.91 & 1.38 \\
\hline PS-4 & 565 & 613 & 710 & 770 & 543 & 1,006 & 1.04 & 1.42 \\
\hline
\end{tabular}

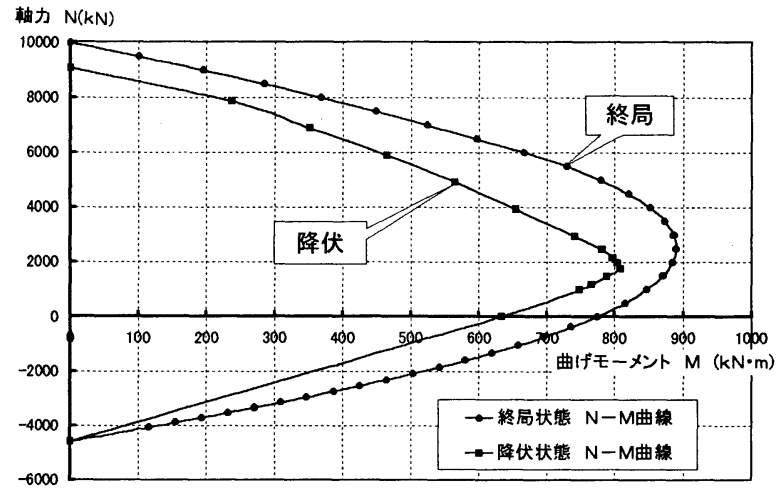

図一20 はり部材のN-M曲線

f c : 充填コンクリートの圧縮強度

$\sigma$ ys : 鋼管の降伏応力度

$\mathrm{t}:$ : 鋼管の板厚

中立軸加らの距離

$$
\begin{array}{ll}
\text { 鋼管圧縮部 } & : \mathrm{y}_{1}=\mathrm{Gsc} / \mathrm{Asc}-\mathrm{e} \\
\text { 鋼管引張部 } & : \mathrm{y}_{2}=\mathrm{Gst} / \mathrm{Ast}+\mathrm{e} \\
\text { 充填部 } & : \mathrm{y}_{3}=\mathrm{Gcc} / \mathrm{Acc}-\mathrm{e}
\end{array}
$$

数值計算に用いる材料特性は，鋼材については降伏忘力 度 $\sigma \mathrm{y}$ を最大值としたバイリニア型, 充填コンクリートに ついはコンクリート標準示方書記載の引張を無視した応 カ一ひずみ曲線を用いた。 図一20 には，式(4),(5)を用いて 計算したはり部材のN-M曲線図を示す.

\section{c）降状荷重と最大荷重の実験值と理論値の比較}

表一 12 における降伏荷重と最大荷重の実験值と理論值 の比較において，降伏荷重の場合，理論值が実験值を上回 る理由として，理論値算出のための忘力分布を図一17 のよ うに $45^{\circ}$ の下面まで降伏としたことによると考えられる. また，最大荷重の比較において，理論值が実験值を下回る 理由は，理論值算出に際し，充填コンクリートのコンファ イド効果を考慮していないことなどが考えられる.
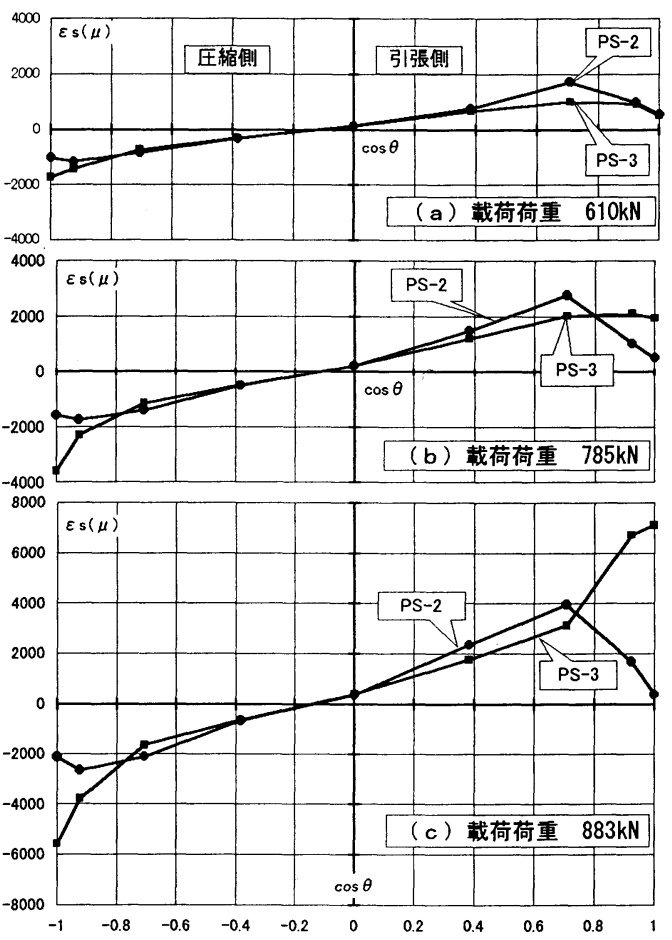

図一21 (ㅂ)断面のひずみ分布比較

\section{（4）ダイヤフラムの位置の相違による比較}

柱内に配置したダイヤフラムの位置の相違による比較を P S - 2 (図一 2(a) $45^{\circ}$ 配置) とP S - 3 (図一 2(b)端 部配置) で行った. 図一21 には各荷重における内断面（は り接合部より $50 \mathrm{~mm}$ の位置) のひずみ分布を比較した。

引張側に着目すると，450配置にした場合（P S - 2) は必ずどの荷重レンジにおいてもダイヤフラムとはりの交 点（x軸：0.71）にひずみのピークが認められる. 一方, 両端部に配置した場合（PS - 3） は載荷荷重 $785 \mathrm{kN}$ 付 近を超えてさらに荷重を増加させた $883 \mathrm{kN}$ にかけて端部 への応力集中が極端に増加していることが図－21(b)，(c) から読みとれる. 
表-13 剛性比（実験値）

\begin{tabular}{|c|c|c|c|c|}
\hline $\begin{array}{c}\text { 供試体 } \\
\text { 番号 }\end{array}$ & $\begin{array}{c}\text { 載荷何重 } \\
\mathrm{P}(\mathrm{kN})\end{array}$ & $\begin{array}{c}\text { 変位 } \delta \\
(\mathrm{mm})\end{array}$ & $\begin{array}{c}\mathrm{P} / \delta \\
(\mathrm{kN} / \mathrm{mm})\end{array}$ & 剛性比 \\
\hline $\mathrm{P} \mathrm{S}-1$ & 393 & 10.344 & 38.0 & $(1.00)$ \\
\hline $\mathrm{P} \mathrm{S}-2$ & 398 & 5.792 & 68.7 & 1.81 \\
\hline $\mathrm{P} \mathrm{S}-3$ & 395 & 5.816 & 67.9 & 1.79 \\
\hline $\mathrm{P} \mathrm{S}-4$ & 389 & 5.816 & 66.9 & - \\
\hline
\end{tabular}

圧縮側に着目すると, $45^{\circ}$ 配置の場合（P S - 2) は, $-22.5^{\circ}$ （x軸 : -0.92）にひずみのピークはあるものの 極端な応力集中は見られない，一方，両端部に配置した場 合（PS-3）は端部での応力集中が見られる. PS - 2 とPS - 3の比較において, PS - 2 の $45^{\circ}$ に配置した ダイヤフラムにより, 鋼とコンクリートの荷重がより効果 的に作用しているものと考えられる.

設計にあたっては，ダイヤフラムを $45^{\circ}$ 配置した方が どの荷重レンジにおいても応力集中の位置とその大きさを 推定しやすいといった利点を有す。

\section{（5）数值計算上の弾性係数比 nの評価}

鋼とコンクリートの合成断面の剛性を算出する場合には, 鋼とコンクリートの弾性係数比 $\mathrm{n}$ を評価する必要がある. 表-13 には実験值において, 未充填型モデルP S - 1 を 1.00 とした場合のP S - 2, 3 の剛性比を求めた. 表-14 には骨組解析を行い弾性係数比をパラメー夕にして剛性比 を計算した結果を示す。

表ー13 における剛性比に対応した弾性倸数比は，おおむ ね表-14のn＝6を用いれば啇応するものと考えられ，そ れは供試体に用いた材料の弾性係数比（Es/Ec = 6.3）に 相当する.

\section{5. まとめ}

今回の載荷実験, およびF EM解析において以下のこと が判明した。

（1) 表-5（降伏時荷重，および最大荷重）から, d $/ \mathrm{D}$ $<0.8, \quad \mathrm{t} / \mathrm{T}<0.8, \mathrm{D} / \mathrm{T}<50, \mathrm{~d} / \mathrm{t}<50$ の範囲 においては，隅角部が降伏耐力を超えても柱部材は降 伏に至らないことか確認された．また，隅角部の耐力 は, 式(4), 式(5)を用いて, おおむねその值を求めるこ とができる.
表-14 弾性係数比nに対する剛性比（骨組解析値）

\begin{tabular}{|c|c|c|c|c|c|}
\hline 弾性係数比 $\mathrm{n}$ & 6 & 7 & 8 & 9 & 10 \\
\hline 剛性比 & 1.88 & 1.76 & 1.67 & 1.59 & 1.54 \\
\hline
\end{tabular}

(2) 表-8（コンクリート充填による耐力増分）から，コ ンクリートの充填効果は, 補剛材（柱内の補剛）の有 無，および位置に依存せずほぼ一定であると認められ た.

(3) 図一21（世断面のひずみ分布比較）より，はり部材の 断面中心から $45^{\circ}$ 位置にダイヤフラムを配置したP S -2のケースは，鋼とコンクリートが良好に荷重を分 担し，断面内のひずみ分布に規則性を有し，ひずみ分 布の急変が生じにくいと考えられる.

(4) 実験と理論計算值を比較すると弾性係数比は，おおむ ね $\mathrm{n}=6$ であり，鋼コンクリートそれぞれの供試体か ら得られた弾性係数の比とほぼ一致する.

(5) 円形コンクリート充填鋼管ラーメンのじん性率は， $\mu$ $=15$ 程度期待でき，未充填円形鋼管，充填角形鋼管の モデルの，おおむね 2 倍程度と評価できる.

（6) 図一6（荷重一変位曲線）より, 角形鋼管ばりのケ一 スと比較し，はり部材に円形鋼管を用いた方が局部座 屈の進行が遅く，かつ降伏以降の比較では耐荷力低下 は少なく，じん性に富むことが確認された.

\section{付録 疲労実験後の静的載荷実硂結果}

実物寸法の約 1/2.5 サイズの供試体を用いた本論文中の 静的載荷実験とは別に，実物寸法の約 $1 / 4$ サイズの供試体 を用い疲労実験（200 万回繰り返し実験）を行い，疲労損 傷が発生していないことを確認した．また，疲労実験終了 後，同一の 2 供試体を用いて，その後の静的耐力が損なわ れていないことを確認するため静的載荷実験を行ったので, その結果を補足する. 主寸法は, 柱サイズ： $\phi 318.5 \times 6.9$ $(\mathrm{D} / \mathrm{T}=46)$, はりサイズ $267.4 \times 6.0(\mathrm{~d} / \mathrm{t}=45)$, $\mathrm{d} / \mathrm{D}=0.84$, ダイヤフラム $\mathrm{t}=6 \mathrm{~mm}\left(45^{\circ}\right.$ 配置 : P S - 2 と同じ) とした. 疲労実験は，図一22(a)に示すラーメ ンを製作し，中央部に繰り返し荷重を載荷した．導入した 隅角部の曲げモーメントは，実橋のラーメンにおいて発生 する応力振幅の 2 倍を想定している．供試体には，P $\max$ $=161 \mathrm{kN}, P \min =91 \mathrm{kN}$ を繰返し載荷した. 本実験終了 後, ラーメンを中央で分割して, 本文で示す載荷方法と同 


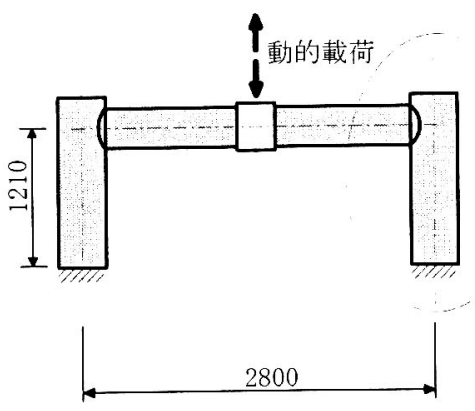

(a) 疲労実験

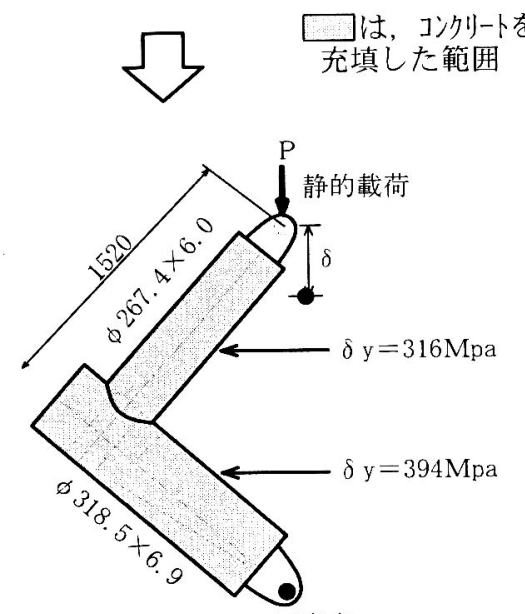

（b）静的載荷実験

\section{図-22 載荷実験概要図}

様に静的荷重を載荷し, 破壊に至らしめた。

載荷荷重 $165 \mathrm{kN}$ を超えたあたりから $\mathrm{P}-\delta$ （図一23 参 照) の傾きが変化し始めたので，一度除荷を行い残留変位 を測定した (残留変位: 約 $5 \mathrm{~mm}$ ) 後, 再度何重を加えた. $\mathrm{P}-\delta$ 関係の傾きは $180 \mathrm{kN}$ 付近より大きくなり始めるも のの, P S - 2 及びP S -3 と同様に荷重低下は見られな い. はり部材の局部座屈が目視で確認できたのは, $215 \mathrm{kN}$

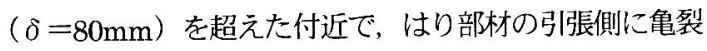
が発生したのは， $\delta=250 \mathrm{~mm}$ 付近であった. 破断した位 置は，PS - 2 上同じ位置（接合部付近のはり引張側端部） であった

本実験においても, 実験值/理論值の比較を行ったが, 降伏 : 0.95, 全断面降伏 : 1.31 となり, 表一14に示寸值と ほぼ同程度の值を示した.

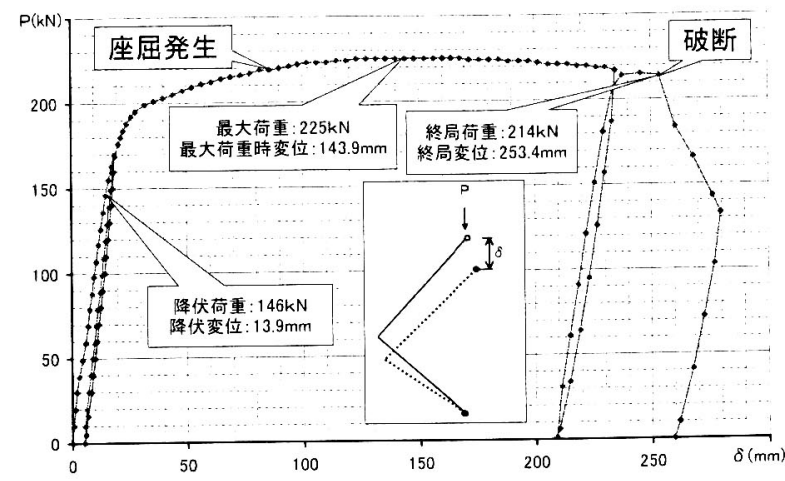

図-23 $\mathrm{P}-\delta$ 曲線

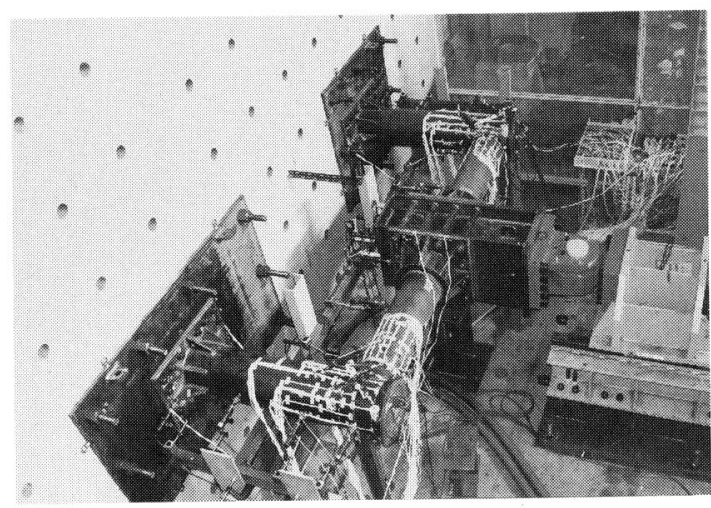

写真 -2 疲労実験試験の状況写真

\section{考文献}

1) 佐藤孝典 : 円形断面の充填鋼管コンクリート構造におけ るコンファイド効果のメカニズムとそのモデル化，日本 建築学会構造系論文報告集 第 452 号, pp. $149 \sim 158$, 1993.10 .

2）鉄道構造物等設計標準 - 同解説 而震設計, 運輸省鉄道 局監修，鉄道総合技術研究所編，1999.10。

3）保坂鐵矢, 西海健二, 中村俊一: 圧縮強度およびヤング 係数の異なるコンクリート系材料を充填した鋼管の曲げ 性能に関する実験的研究, 構造工学論文集 Vol.44A, pp.1565 1573, 1998.3.

4）中井博, 吉川紀, 村本和之：コンクリートを充填した長 方形鋼製橋脚の梁・柱隅角部の耐荷力に関する実験的研 究, 構造工学論文集, Vol.33A, pp.327～340, 1987.3.

5）山口栄輝, 市川篤司, 池田学, 久保知徳, 三木干寿 : 繰 り返し荷重を受ける鋼製ラーメン隅角部におけるハンチ の効果, 構造工学論文集 Vol.46A，pp.119 125，2000.3.

6）黄元熎, 西村宣男, 高津秀俊 : 鋼製ラーメン橋隅角部の 
強度と変形能に関する実験的研究, 構造工学論文集

Vol.40A, pp.201 214, 1994.3 .

7）中井博, 福岡悟, 酒造敏廣, 明橋克良: 鋼製ラーメン隅 角部の Shear lag と耐荷力とに関する実験的研究，構造 工学論文集 Vol.33A，pp.193～206，1987.3.

8) American Petroleum Institute : Recommended Practice for Planning, Designing and Constructing Fixed Offshore Platforms. Section 4.3 Tubular Joints, pp.39〜 44, 1991.
9） 日本道路協会：道路橋示方書，II. 鋼橋編，12.6.5 格点 構造, pp.338 341, 1996.12 .

10）鉄道構造物等設計標準・同解説 鋼とコンクリートの複合 構造物, 運輸省鉄道局監修, 鉄道総合技術研究所編, 1998.10. 付属資料-10 コンクリート充填鋼管柱（円形断面）部材 の曲け降伏耐力，降伏変位の算出法

\section{THE STATIC LOAD CARRYING CAPACITY OF A CORNER JOINT OF CONCRETE FILLED CIRCULAR STEEL COLUMN}

\section{Noriyuki HORICHI, Tetsuya HOSAKA, Teruhiko YODA, Shinichi KATSUO}

This paper deals with load carrying capacity of corner joints between concrete filled steel columns and beams, with the help of loading tests and FEM analyses. For the loading tests, the model tests were carried out on four specimens by changing the position of stiffeners, the cross-section of beams. In the FEM analysis, six models were compared with each other to supplement the loading tests. As a result, it was found that each filling concrete in the corner hollow section has a constantly strong effect on the ultimate strength of corner joints regardless of whether the ring stiffeners are applied or not. The loading tests also confirmed that filling concrete circular steel pipes used for beam members were expected to two times post-yielding ductility to that of the filling concrete rectangular section member, the hollow circular section one. 